\title{
Regional climate control of glaciers in New Zealand and Europe during the pre-industrial Holocene
}

\author{
Aaron E. Putnam ${ }^{1,2 \star}$, Joerg M. Schaefer ${ }^{1,3}$, George H. Denton ${ }^{2}$, David J. A. Barrell ${ }^{4}$, Robert C. Finkel ${ }^{5}$, \\ Bjørn G. Andersen ${ }^{6}$, Roseanne Schwartz ${ }^{1}$, Trevor J. H. Chinn ${ }^{7}$ and Alice M. Doughty ${ }^{8}$
}

\begin{abstract}
Mountain glaciers worldwide have undergone net recession over the past century in response to atmospheric warming ${ }^{1}$, but the extent to which this warming reflects natural versus anthropogenic climate change remains uncertain ${ }^{2,3}$. Between about 11,500 years ago and the nineteenth century, progressive atmospheric cooling over the European Alps induced glacier expansion ${ }^{2,4-6}$, culminating with several large-scale advances during the seventeen to nineteenth centuries ${ }^{3}$. However, it is unclear whether this glacier behaviour reflects global or a more regional forcing. Here we reconstruct glacier fluctuations in the Southern Alps of New Zealand for the past 11,000 years using ${ }^{10} \mathrm{Be}$ exposure ages. We use those fluctuations to estimate the associated temperature variations. On orbital to submillennial timescales, changes in glacier snowlines in New Zealand were linked to regional climate and oceanographic variability and were asynchronous with snowline variations in European glaciers. We attribute this asynchrony to the migration of the intertropical convergence zone. In light of this persistent asynchrony, we suggest that the net glacier recession and atmospheric warming in both regions over the past century is anomalous in the context of earlier Holocene variability and corresponds with anthropogenic emissions of greenhouse gases.
\end{abstract}

The Southern Alps are well positioned to record Holocene climate changes ${ }^{7}$. Situated on New Zealand's South Island in the southwestern Pacific Ocean, this mountain range lies in the zone of interaction between the belts of subtropical highs and subpolar lows that demarcate the westerly wind belt, whereas South Island inflects the subtropical front where subtropical and subantarctic water masses converge (Fig. 1). Located in a highprecipitation maritime environment, glaciers of the Southern Alps are highly sensitive monitors of atmospheric temperature because of rapid ice throughflow from accumulation to melting zones ${ }^{8}$. Therefore, moraine ridges can be used to reconstruct the former geometries of glaciers, enabling estimation of former equilibriumline (snowline) altitudes that reflect atmospheric temperatures. Here we combine moraine geomorphology with high-precision ${ }^{10} \mathrm{Be}$ surface-exposure dating ${ }^{7,9}$, to reconstruct glacier fluctuations and atmospheric temperatures in the Southern Alps during the Holocene interglaciation. We then compare this reconstruction

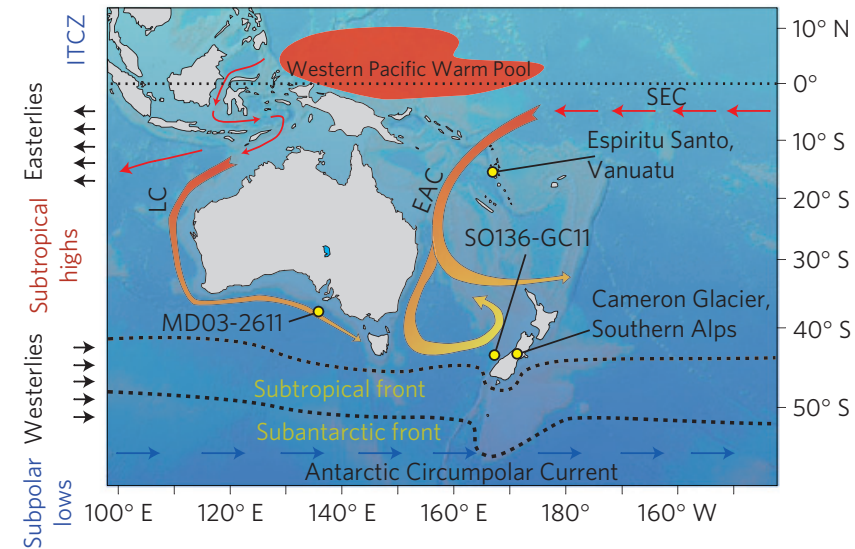

Figure 1 | Map of the southwest Pacific region. Coloured arrows depict generalized ocean currents. Yellow dots mark locations of pertinent records mentioned in text. LC, Leeuwin Current; SEC, South Equatorial Current.

with glacier records from the European Alps to assess whether Holocene climate evolved coevally on opposite sides of the planet.

We targeted the exceptionally well-preserved moraines of Cameron Glacier $\left(\sim 43^{\circ} \mathrm{S}, \sim 171^{\circ} \mathrm{E}\right)$, which drains a $\sim 6 \mathrm{~km}^{2}$ catchment in the Arrowsmith Range of the central Southern Alps. Following the end of the past glaciation, Cameron Glacier receded into the upper reaches of its valley and constructed a prominent set of late-glacial moraines $\sim 5 \mathrm{~km}$ down-valley of its modern terminus ${ }^{10}$. Up-valley of these late-glacial moraines is a sequence of ten well-preserved bouldery terminal moraine ridges marking a succession of progressively less-extensive advances of Cameron Glacier (see Supplementary Information and Fig. S4). Embedded in the crests of these moraine ridges are large greywacke boulders amenable to ${ }^{10} \mathrm{Be}$ surface-exposure dating ${ }^{7}$.

We obtained $45{ }^{10} \mathrm{Be}$ surface-exposure ages from the Cameron Glacier Holocene moraine system (Fig. 2 and Supplementary Fig. S13 and Tables S1-S3). Where possible, we sampled at least three different boulders on each moraine ridge and the ages show excellent internal consistency. Arithmetic mean surfaceexposure ages $( \pm 1 \sigma$; expressed in years before $\mathrm{AD} 1950$, also

\footnotetext{
${ }^{1}$ Lamont-Doherty Earth Observatory, 61 Rt. 9W, Palisades, New York 10944, USA, ${ }^{2}$ Department of Earth Sciences and Climate Change Institute, University of Maine, Orono, Maine 04469, USA, ${ }^{3}$ Department of Earth and Environmental Sciences, Columbia University, New York, New York 10027, USA, ${ }^{4}$ GNS Science, Private Bag 1930, Dunedin, New Zealand, ${ }^{5}$ Department of Earth and Planetary Sciences, University of California, Berkeley, California 95064, USA, ${ }^{6}$ Department of Geosciences, University of Oslo, 0316-Oslo, Norway, ${ }^{7}$ Alpine and Polar Processes Consultancy, Lake Hawea, New Zealand, ${ }^{8}$ Antarctic Research Centre and School of Earth Sciences, Victoria University of Wellington, PO Box 600, Wellington, New Zealand. ‘Deceased. *e-mail:aputnam@ldeo.columbia.edu.
} 




Figure 2 | Glacial geomorphologic map of the Cameron Glacier valley, Southern Alps, New Zealand. All features and boundaries are described in the legend (inset). White boxes show ${ }^{10}$ Be surface-exposure ages (in years before AD 1950) and yellow dots are sample locations. Ages in italics are statistical outliers. Twentieth-century terminus positions are represented by bold black lines on the map and their ages are in grey boxes. Red numbers correspond to ${ }^{10}$ Be sample identification labels. Map is adapted from ref. 30.

referred to here as yr ago), for the ten outermost to innermost moraines, are: $10,690 \pm 410 \mathrm{yr}(n=6) ; 9,840 \pm 470 \mathrm{yr}(n=6$; one outlier removed); $9,140 \pm 280 \mathrm{yr}(n=2) ; 8,670 \pm 290 \mathrm{yr}(n=1)$; $8,190 \pm 230 \mathrm{yr} \quad(n=5) ; 7,190 \pm 120 \mathrm{yr}(n=4) ; 6,890 \pm 190 \mathrm{yr}$ $(n=4) ; 652 \pm 27 \mathrm{yr}(n=4$; one outlier removed $) ; 523 \pm 61 \mathrm{yr}$ ( $n=9$; three outliers removed); and $180 \pm 48 \mathrm{yr}$ ( $n=4$; one outlier removed). The moraine dated to $180 \mathrm{yr}$ ago (about $\mathrm{AD} 1770$ ) is at or near the position of the Cameron Glacier terminus depicted in a painting by Julius Haast in AD 1864 (ref. 10). The innermost discernible ridge in the sequence was deposited in about AD 1930 (see Supplementary Information) and previous studies $^{10,11}$ documented $\mathrm{AD} 1964$ and $\mathrm{AD} 1989$ positions of the Cameron Glacier terminus (Fig. 2).

We reconstructed the geometry of Cameron Glacier at four key terminal moraine positions and calculated the associated snowline using the accumulation area-altitude ratio method (Supplementary Fig. S17). Striking correlation between snowline elevation and glacier terminus position $(\sim 73 \mathrm{~m}$ of snowline rise per $1 \mathrm{~km}$ of terminus retreat; $r^{2}=0.99$; Supplementary Fig. S19) allowed us to determine snowlines for moraines intermediate between those used for area-altitude ratio snowline analyses (see Supplementary Information). Taking snowline changes as a direct proxy for temperature (see Supplementary Information), we used an adiabatic lapse rate of $-0.0065^{\circ} \mathrm{C} \mathrm{m}^{-1}$ to convert these snowline changes to estimates of temperature change.

Our ${ }^{10} \mathrm{Be}$ moraine chronology shows that Cameron Glacier achieved its largest Holocene extents at 10,690 \pm 410 and $9,840 \pm 470$ yr ago. The snowline at that time was $\sim 240 \mathrm{~m}$ below present-day values, equating to a temperature $\sim 1.6^{\circ} \mathrm{C}$ cooler than now. The glacier then underwent oscillatory retreat until $6,890 \pm 190 \mathrm{yr}$ ago; this $1 \mathrm{~km}$ retreat over $\sim 3,000 \mathrm{yr}$ implies an overall $90 \mathrm{~m}$ rise in snowline and temperature amelioration to $\sim 1.0^{\circ} \mathrm{C}$ cooler than now. Ice advance during the past millennium abutted the middle-Holocene moraines, depositing ridges $650 \pm 30$ and $520 \pm 60 \mathrm{yr}$ ago, implying a latest Holocene return to snowline and temperature conditions as prevailed $\sim 6,900 \mathrm{yr}$ ago. Progressive retreat over the past $\sim 520 \mathrm{yr}$ was punctuated by stillstands or minor readvances in about $\mathrm{AD} 1770, \mathrm{AD} 1864$ and $\mathrm{AD} 1930$. Net retreat of 460 m between $\mathrm{AD} 1864$ and $\mathrm{AD} 1930$ (averaging $\sim 0.7 \mathrm{~m} \mathrm{yr}^{-1}$ ) represents a snowline rise of $\sim 0.5 \mathrm{~m} \mathrm{yr}^{-1}$ and warming of $\sim 0.4{ }^{\circ} \mathrm{C}$ 


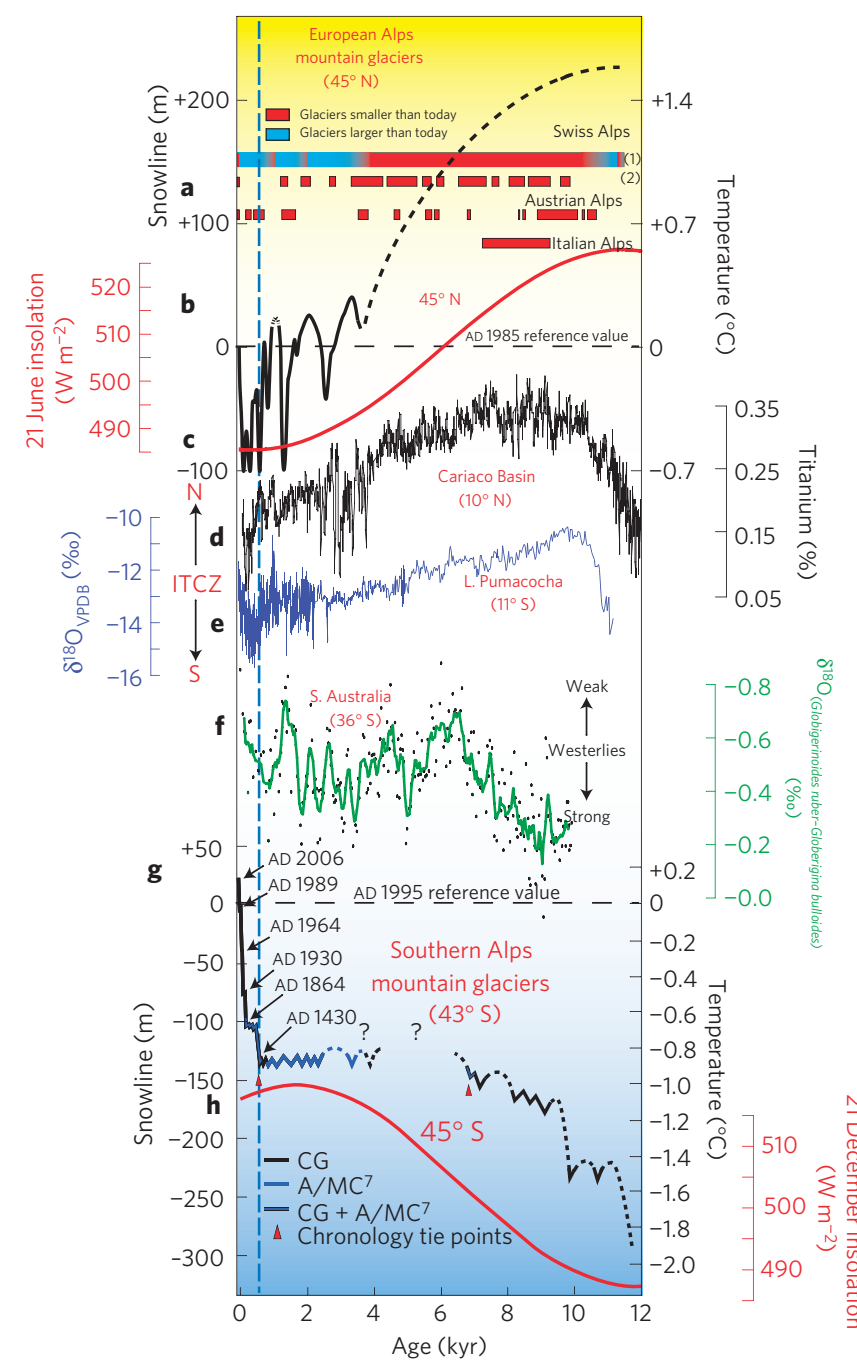

Figure 3 | Glacier-inferred temperature records compared with proxies for the position of the ITCZ. a, European Alps glacier extents compared with today: Switzerland ((1) ref. 6 and (2) refs 2,4,5), Austria ${ }^{14}$ and Italy ${ }^{13}$.

b, European Alps snowlines and temperatures constructed from refs 3,4.

c, Boreal summer insolation. d, Cariaco Basin percentage Ti (bulk fraction) and e, Peruvian lacustrine $\delta^{18} \mathrm{O}$ (ref. 21), reflecting ITCZ latitude. f, Marine proxy for westerlies from core MD03-2611 (ref. 20). g, Southern Alps composite snowlines/temperatures. CG, Cameron Glacier; A/MC, Aoraki/Mount Cook glaciers. h, Austral summer insolation. Dotted blue line denotes the onset of late-Holocene recession (advance) of the Southern Alps (European) glaciers.

per century. Between AD 1930 and AD 2006, an average retreat rate of $17.5 \mathrm{~m} \mathrm{yr}^{-1}$ implies snowline rise of $\sim 1.3 \mathrm{~m} \mathrm{yr}^{-1}$ and temperature increase averaging $0.83 \pm 0.24{ }^{\circ} \mathrm{C}$ per century (see Supplementary Information and Fig. S20). Our glacier-inferred temperature estimates are consistent with the instrumentally recorded New Zealand mean annual temperature rise (AD 1909-2009) of $0.93 \pm 0.28^{\circ} \mathrm{C}$ per century ${ }^{12}$ (Supplementary Fig. S20).

Combining the moraine-forming events at Cameron Glacier with those from Mueller, Hooker and Tasman glaciers, located $\sim 85 \mathrm{~km}$ farther southwest ${ }^{7}$, provides a composite chronology of Southern Alps glacier fluctuations $\left(n=\sim 120{ }^{10}\right.$ Be ages; Supplementary Table S6) that is a proxy for atmospheric temperature during the Holocene (Fig. 3). Our glacier-based reconstruction of Holocene atmospheric temperatures in the Southern Alps differs markedly from glacier-inferred summer temperature reconstructions from the European Alps. Radiocarbon ${ }^{2,4,5,13}$, dendrochronological ${ }^{14}$, archaeological ${ }^{15}$ and cosmogenic-nuclide ${ }^{6}$ studies indicate that glaciers in the European Alps have been smaller than present for most of the Holocene. Early Holocene ( 10,000-8,000 yr ago) snowlines were as much as $220 \mathrm{~m}$ higher and summer temperatures $>1{ }^{\circ} \mathrm{C}$ warmer than now ${ }^{4}$ (Fig. 2). In contrast, our Southern Alps record shows atmospheric temperatures colder than at present for the first part of the Holocene and, since $\sim 6,900 \mathrm{yr}$ ago, fluctuating at close to latest Holocene values. Furthermore, most glaciers in the European Alps attained their greatest Holocene extents in the seventeenth and nineteenth centuries $^{3,6}$, whereas the last major advance of Cameron Glacier, mirrored at Mueller Glacier, culminated several centuries earlier well inside the early to mid-Holocene limit and was followed by snowline rise and glacier recession.

The long-term asynchronous trend of glacier behaviour in the European and Southern Alps is consistent with antiphased patterns of 21 June $45^{\circ} \mathrm{N}$ and 21 December $45^{\circ} \mathrm{S}$ insolation signals ${ }^{16}$. One possibility is that bihemispheric glacier behaviour reflects direct opposite forcing by antiphased summer-insolation signals. A difficulty with this interpretation is that Southern Alps snowlines stabilized about $140 \mathrm{~m}$ below present-day values shortly after $7,000 \mathrm{yr}$ ago, preceding the $45^{\circ} \mathrm{S}$ summer-insolation maximum by more than four millennia. Moreover, glacier mass balance in the Southern Alps is more responsive to turbulent heat fluxes than to summertime radiation forcing ${ }^{17}$. In other words, atmospheric temperatures, integrating upwind sea surface temperatures (SSTs) and modulated by regional wind direction, would overpower direct radiative forcing of glacier behaviour in the Southern Alps ${ }^{17}$. Indeed, periods of glacier advance (retreat) in recent decades have been robustly linked to intervals of enhanced cold southwesterly (warm northeasterly) flow over South Island ${ }^{18}$.

We consider that asynchronous glacier behaviour is most readily explained by the effects of insolation-driven southward migration of the intertropical convergence zone (ITCZ; that is, Earth's thermal equator $)^{19}$ on southwest Pacific climate ${ }^{20}$. Progressive Holocene southward migration of Earth's thermal equator, as shown by hydrological records from locations north ${ }^{19}$ and south ${ }^{21}$ of the equatorial Andes, has gradually increased the flow of relatively warm, northerly quarter air over the Southern Alps, resulting in snowline rise and glacier recession ${ }^{22}$. Palaeo-oceanographic data from south of Australia ${ }^{20}$ (Figs 1 and 3) indicate overall weakening of the southern westerlies during the Holocene, attributable to southward movement of the ITCZ, which in turn induced southward migration of the subtropical and subantarctic fronts (for example, ref. 20).

Another notable observation is that of early to middle-Holocene warming of the East Australian Current (EAC) indicated by coralbased SST records from Vanuatu ${ }^{23}$. We suggest that this warming reflects eastward migration of the Western Pacific Warm Pool during the Holocene, attributed to southward movement and/or weakening of the trade winds ${ }^{24}$. A warmer EAC, which feeds tropical water into the Tasman Sea (Fig. 1), may have further stimulated glacier recession downwind in the Southern Alps, exacerbating the effects of the ITCZ migration.

A puzzle is that alkenone-inferred SSTs from marine cores in the vicinity of the subtropical front in the Australasian region, and thus close to the northern edge of the Southern Ocean, have declined by as much as $\sim 2.0^{\circ} \mathrm{C}$ since the early Holocene (for example, cores MD03-2611 (ref. 25) and SO136-GC11 (ref. 26) see Fig. 1 for core locations). One explanation is that these SST trends reflect the signature of the Southern Ocean, which has been cooling since the early Holocene ${ }^{27}$. Depending on core location relative to oceanic upwelling, Southern Ocean waters may have overwhelmed the signature of tropical water derived from the equatorial Pacific ${ }^{23}$. Further acquisition of robust palaeo-oceanographic records in the central and northern Tasman Sea may help to clarify the overall factors influencing SSTs in the Australasian region. 
Altogether, we propose that atmospheric and oceanic effects of insolation-driven southward relaxation of Earth's thermal equator $^{19,21}$ stimulated Holocene glacier recession in the New Zealand Southern Alps coincident with glacier expansion in the European Alps. Still requiring explanation, however, is the cause of submillennial oscillations superimposed on overall Holocene climate trends. A leading possibility again involves Earth's thermal equator $^{19,28,29}$, but relates to centurial scale fluctuations in its mean position. For example, the onset of Northern Hemispheric cooling, as registered by glaciers in the European $\mathrm{Alps}^{3}$, was accompanied by a southward shift of the ITCZ from the AD 1400s to the AD 1600s ( 500-400 yr ago; Fig. 3; refs 19,28,29). At the same time, snowlines began to rise in the Southern Alps and the $\sim 520 \mathrm{yr}$ moraines were abandoned by Cameron and Mueller glaciers. This snowline signature is consistent with a concomitant southward migration of Earth's thermal equator ${ }^{19,28,29}$, associated poleward movement of the southern subtropical high-pressure belt ${ }^{18}$ and possibly a coeval southward shift of the subtropical and subantarctic fronts ${ }^{20}$. The opposite situation may have occurred during Medieval time $(\sim 1,200-900 \mathrm{yr}$ ago $)$ when warm conditions prevailed in the North Atlantic region ${ }^{3}$, the ITCZ maintained a northerly position ${ }^{19,29}$ and glaciers of the Southern Alps were larger than in the nineteenth century ${ }^{7}$.

Asynchronous behaviour of glaciers in the European Alps and Southern Alps seems to be an intrinsic feature of Holocene climate variability on orbital and submillennial timescales, but is inconsistent with coeval net warming and glacier recession over the twentieth century. Net glacier recession during the past century requires forcing capable of producing synchronous warming on opposite sides of the planet. In this regard, buildup of fossil $\mathrm{CO}_{2}$ in the atmosphere, together with attendant global effects and feedbacks on Earth's radiation balance, could explain anomalously synchronous warming and glacier retreat in the European and Southern Alps since the beginning of the industrial age.

\section{Received 8 March 2012; accepted 13 July 2012; published online 12 August 2012}

\section{References}

1. Oerlemans, J. Extracting a climate signal from 169 glacier records. Science 308, 675-677 (2005).

2. Hormes, A., Beer, J. \& Schlüchter, C. A geochronological approach to understanding the role of solar activity on Holocene glacier length variability in the Swiss Alps. Geografis. Ann. 88A, 281-294 (2006).

3. Holzhauser, H., Magny, M. \& Zumbühl, H. J. Glacier and lake-level variations in west-central Europe over the last 3500 years. Holocene 15, 789-801 (2005).

4. Joerin, U. E., Nicolussi, K., Fischer, A., Stocker, T. F. \& Schlüchter, C. Holocene optimum events inferred from subglacial sediments at Tschierva Glacier, Eastern Swiss Alps. Quat. Sci. Rev. 27, 337-350 (2008).

5. Joerin, U. E., Stocker, T. F. \& Schlüchter, C. Multicentury glacier fluctuations in the Swiss Alps during the Holocene. Holocene 5, 697-704 (2006).

6. Goehring, B. M. et al. Rhone Glacier was smaller than today for most of the Holocene. Geology 39, 679-682 (2011).

7. Schaefer, J. M. et al. High-frequency Holocene glacier fluctuations in New Zealand differ from the northern signature. Science 324, 622-625 (2009).

8. Anderson, B. \& Mackintosh, A. Controls on mass balance sensitivity of maritime glaciers in the Southern Alps, New Zealand: The role of debris cover. J. Geophys. Res. 117, F01003 (2012).

9. Putnam, A. E. et al. In situ cosmogenic ${ }^{10}$ Be production-rate calibration from the Southern Alps, New Zealand. Quat. Geochronol. 5, 392-409 (2010).

10. Burrows, C. J. Late Pleistocene and Holocene moraines of the Cameron valley, Arrowsmith Range, Canterbury, New Zealand. Arctic Alpine Res. 7, 125-140 (1975).

11. Burrows, C. J., Duncan, K. W. \& Spence, J. R. Aranuian vegetation history of the Arrowsmith Range, Canterbury II. Revised chronology for moraines of the Cameron Glacier. New Zealand J. Bot. 28, 455-466 (1990).

12. Mullan, A. B., Stuart, S. J., Hadfield, M. G. \& Smith, M. J. Report on the review of NIWA's 'Seven-Station' temperature series. NIWA Inform. Ser. 78, 175 (2010).

13. Porter, S. \& Orombelli, G. Glacier contraction during the middle Holocene in the western Italian Alps: Evidence and implications. Geology 13, 296-298 (1985).
14. Nicolussi, K. \& Patzelt, G. Discovery of early-Holocene wood and peat on the forefield on the Pasterze Glacier, Eastern Alps, Austria. Holocene 10, 191-199 (2000).

15. Grosjean, M., Suter, P. J., Trachsel, M. \& Wanner, H. Ice-borne prehistoric finds in the Swiss Alps reflect Holocene glacier fluctuations. J. Quat. Sci. 22, 203-207 (2007)

16. Milankovitch, M. Kanon der Erdbestrahlung und seine Andwendung auf das Eiszeiten-problem (R. Serbian Acad., 1941)

17. Anderson, B. et al. Climate sensitivity of a high-precipitation glacier in New Zealand. J. Glaciol. 56, 114-128 (2010).

18. Fitzharris, B. B., Clare, G. R. \& Renwick, J. Teleconnections between Andean and New Zealand glaciers. Glob. Planet. Change 59, 159-174 (2007).

19. Haug, G. H., Hughen, K. A., Sigman, D. M., Peterson, L. C. \& Rohl, U. Southward migration of the intertropical convergence zone through the Holocene. Science 293, 1304-1308 (2001).

20. Moros, M., De Deckker, P., Jansen, E., Perner, K. \& Telford, R. J. Holocene climate variability in the Southern Ocean recorded in a deep-sea sediment core off South Australia. Quat. Sci. Rev. 28, 1932-1940 (2009).

21. Bird, B. W., Abbott, M. B., Rodbell, D. T. \& Vuille, M. Holocene tropical South American hydroclimate revealed from a decadally resolved lake sediment $\delta^{18} \mathrm{O}$ record. Earth Planet. Sci. Lett. 310, 192-202 (2011).

22. Harrington, H. J. Glacier wasting and retreat in the Southern Alps of New Zealand. J. Glaciol. 2, 140-144 (1952).

23. Beck, J. W., Recy, J., Taylor, F., Edwards, R. L. \& Cabioch, G. Abrupt changes in early Holocene tropical sea surface temperature derived from coral records. Nature 385, 705-707 (1997).

24. Linsley, B. K., Rosenthal, Y. \& Oppo, D. W. Holocene evolution of the Indonesian throughflow and the western Pacific warm pool. Nature Geosci. 3 , 578-583 (2010).

25. Calvo, E., Pelejero, C., De Deckker, P. \& Logan, G. A. Antarctic deglacial pattern in a $30 \mathrm{kyr}$ record of sea surface temperature offshore South Australia. Geophys. Res. Lett. 34, L13707 (2007).

26. Barrows, T. T., Lehman, S. J., Fifield, L. K. \& De Deckker, P. D. Absence of cooling in New Zealand and the adjacent ocean during the Younger Dryas chronozone. Science 318, 86-89 (2007).

27. Barrows, T. T., Juggins, S., De Deckker, P., Calvo, E. \& Pelejero, C. Long-term sea surface temperature and climate change in the Australian-New Zealand region. Paleoceanography 22, PA22215 (2007).

28. Sachs, J. P. et al. Southward movement of the Pacific intertropical convergence zone AD 1400-1850. Nature Geosci. 2, 519-525 (2009).

29. Newton, A., Thunell, R. \& Stott, L. Climate and hydrographic variability in the Indo-Pacific Warm Pool during the last millennium. Geophys. Res. Lett. 33, L19710 (2006).

30. Barrell, D. J. A., Andersen, B. G. \& Denton, G. H. in Glacial Geomorphology of the Central South Island, New Zealand (GNS Science Monograph, Vol. 27, 2011).

\section{Acknowledgements}

We thank the Gary C. Comer Science and Education Foundation, the National Oceanographic and Atmospheric Administration and the National Science Foundation (NSF) for support. J.M.S. acknowledges NSF support for this study (grants EAR-0823521 and EAR-0345835). GNS Science's Direct Crown Funded Programme 'Global Change through Time' supported D.J.A.B. We thank the staff of the Center for Accelerator and Mass Spectrometry at Lawrence-Livermore National Laboratory for their careful work and C. J. Burrows, W. S. Broecker, U. Ninnemann, M. R. Kaplan, R. F. Anderson, D. M. Sigman, K. A. Allen and G. R. M. Bromley for discussions. K. A. Allen helped with statistics. B. Lee and D. Perro provided administrative support. Mount Hutt Helicopters provided transportation to and from field sites. P. and A. Todhunter of Lake Heron Station graciously permitted us access to the Cameron valley. We thank the Department of Conservation-Te Papa Atawhai and Te Rünanga o Ngäi Tahu for access onto and sampling of the Cameron Glacier moraines. This paper is LDEO contribution no. 7572.

\section{Author contributions}

A.E.P. helped design the project, conducted field work and laboratory analyses, conducted snowline reconstructions and wrote the paper. J.M.S. and G.H.D. helped design the project and participated in field work. D.J.A.B. and B.G.A. conducted geomorphic mapping. R.S. carried out laboratory work. A.M.D. participated in the field work. T.J.H.C. conducted snowline reconstructions. R.C.F. conducted accelerator mass spectrometer analyses. G.H.D., D.J.A.B., J.M.S. and A.M.D. helped write the paper.

\section{Additional information}

Supplementary information is available in the online version of the paper. Reprints and permissions information is available online at www.nature.com/reprints. Correspondence and requests for materials should be addressed to A.E.P.

\section{Competing financial interests}

The authors declare no competing financial interests. 